\title{
MAJER BALABAN'S COMPETITION FOR THE BEST MA AND PHD THESIS ON JEWISH HISTORY AND CULTURE
}

Among many events held at the Jewish Historical Institute the Majer Balaban Contest for the best Master's and Doctoral thesis on the Jewish subject matter $^{1}$ definitely deserves some closer attention. The 9th edition of this biannual event was held last year and the winners were announced in the autumn of 2020.

The major goals of the contest indicated in its terms and conditions are: to contribute to the development of Polish humanities; to promote people's knowledge of Polish Jews, including their history and culture; to promote researchers who study the subject; and, finally, to create a central information database on the state of the research.

The contest has been held biannually since 1990 with just a short break in the 1990s. Its reputation and reach have been growing steadily as more participants submit their works with each incoming edition. The laureates, who participate in the contest at the very beginning of their scientific careers, commonly become major figures of the academia in the broadly understood humanities focused on Jewish history and culture. Those have included such researchers as Professor Barbara Engelking (today the head of the Polish Centre for Holocaust Research at the Institute of Philosophy and Sociology of the Polish Academy of Sciences), Professor Michał Galas (the head of the Institute of Jewish Studies of the Jagiellonian University), and Professor Andrzej Żbikowski (the head of the Research Department at the Jewish Historical Institute).

\footnotetext{
* Anna M. ROSNER, Jewish Historical Institute, ul. Tłomackie 3/5, 00-090 Warsaw, Poland; e-mail: arosner@jhi.pl, ORCID: https://orcid.org/0000-0003-0053-6000

${ }^{1}$ Konkurs im. Majera Bałabana na najlepsze prace doktorskie i magisterskie o Żydach i Izraelu.
} 
The 9th edition of the contest was organised under the patronage of the Ministry of Culture and National Heritage, the Embassy of Israel in Warsaw, and the Tadeusz Manteuffel Institute of History of the Polish Academy of Sciences. It differed from earlier editions mostly due to the pandemic reality which forced the organisers to move all the activities around the contest online. The jury faced an incredibly hard task as the number of submissions exceeded those from previous years with as many as seventeen Ph.D. thesis and seventeen M.A. dissertations. Many of them discussed topics which were extremely rarely researched or which have never been researched before. A majority of them focused on the 20th century and the Shoah, though there were also entries which discussed earlier centuries, as well as some which focussed on other scientific fields such as literary studies, sociology, history, art, political studies, and the history of law. The 9th edition different a lot from the $8^{\text {th }}$ edition as in 2018 it was micro-history as well as local history, together with literature studies, which dominated. There were also numerous entries on anti-Semitism, and Jewish identification both withing the Jewish world and in non-Jewish communities.

In the Ph.D. thesis category, two ex aequo winners, i.e. Karolina Panz, Ph.D., for her work on the micro-historical perspective applied to the Holocaust victims from the city of Nowy Targ', which she defended at the University of Warsaw, and Mikołaj Smykowski, Ph.D., for his study of the Shoah's ecology and a critical post-camp landscape anthropology study using the example of the Chełm nad Nerem camp ${ }^{3}$, which he wrote at the Adam Mickiewicz University of Poznań. The runner-up was Jan Borowicz, Ph.D., University of Warsaw, for his dissertation on Holocaust perversions and the position of the Polish witness ${ }^{4}$.

In the MA dissertation category, the winner was Krzysztof Bielawski, M.A., the University of Warsaw, for his work on the destruction of Jewish burial grounds in Poland after $1933^{5}$. The runner-up was Joanna Zych, M.A., the War Studies Academy, for her dissertation on a comparative analysis of Zionist armed organisations before $1948^{6}$. The second runner-up was Katarzyna Kiejrys, M.A., the University of Warsaw, who wrote a thesis on American anti-Semitism in the colonial era ${ }^{7}$.

Graduates of both M.A. and Ph.D. studies willing to participate need to submit their works in Polish; if a dissertation is written in a foreign language, it needs to be defended at a Polish university. The submission needs to be supported by

\footnotetext{
${ }^{2}$ Zagłada żydowskich mieszkańców Nowego Targu w perspektywie mikrohistorycznej.

${ }^{3}$ Ekologie Zagłady. Krytyczne studium z antropologii krajobrazu poobozowego na przykładzie Bytego Obozu Zagłady w Chetmnie nad Nerem.

${ }^{4}$ Perwersje holokaustowe. Pozycja polskiego świadka.

${ }^{5}$ Destrukcja cmentarzy żydowskich na terenach obecnej Polski po 1933 roku.

${ }^{6}$ Zbrojne organizacje ruchu syjonistycznego przed 1948 r. - analiza porównawcza.

${ }^{7}$ Old Sentiments in the New World. Patterns of American Antisemitism from the Colonial Times through the Nineteenth Century.
} 
a letter of recommendation from the graduate's scientific tutor. Contest winners receive a diploma along with a cash prize. Additionally, they are offered the opportunity to present their paper at the Jewish Historical Institute seminar. They are also asked to submit an article to the Institute's quarterly: Kwartalnik Historii Żydów. Many of the recognised works have been published as monographs, some by the Institute's publisher. 